\title{
INDEKS KEMAMPUAN KEUANGAN DAERAH DI PROVINSI PAPUA
}

\author{
Boy Piter Nizu Kekry ${ }^{1}$ \\ kekryboy@gmail.com
}

1Dosen Jurusan IImu Ekonomi Fakultas Ekonomi dan Bisnis Universitas Cenderawasih

\begin{abstract}
Abstraksi:
Tujuan utama dalam penelitian Indeks Kemampuan Keuangan Daerah di Provinsi Papua ialah: (1) Mengukur peranan Pendapatan Asli Daerah (PAD) terhadap Belanja Daerah dan Elastisitas Pertumbuhan Ekonomi pada 29 Kabupaten/Kota di Provinsi Papua, (2) Mengukur Indeks Komposit Kemampuan Keuangan Daerah pada 29 Kabupaten/Kota di Provinsi Papua. Pada prinsipnya penelitian ini menggunakan Pendekatan Kuantitatif dengan Lokus pada 29 Kabupaten/Kota di Provinsi Papua dan memiliki fokus pada PAD, Belanja Daerah, dan Pertumbuhan Ekonomi periode tahun 2015-2019, adapun penerapan metode analisis data pada penelitian ini yaitu deskriptif kuantititaif pada pengukuran indeks tunggal dan komposit. Hasil penelitian menunjukkan bahwa (1) Kinerja kuantitas PAD 29 Kabupaten/Kota di provinsi papua yang sebatas terukur dari nilai dekriptif kontribusi dan pertumbuhan tidak dapat dijadikan satu-satunya tolak ukur dalam memandang kinerja realisasi PAD di provinsi papua, (2) Pergerakan percepatan pertumbuhan ekonomi yang cenderung lambat selama ini, belum mampu mengungkit penerimaan PAD pada 29 KabupatenKkota di Provinsi Papua, (3) Kabupaten/Kota yang notabene menjadi barometer, belum sanggup menunjukkan kinerja secara konsisten dalam penilaian Indeks Kemampuan Keuangan Daerah di Provinsi Papua. Dengan ini, rekomendasi aplikatif yang hendak disikapi oleh pemerintah daerah baik provinsi papua dan pemerintah kabupaten/kota ialah: (1) Penyamaan persepsi berbasiskan pada fakta ilmiah dan konseptual mengenai kedudukan dari PAD itu sendiri, melalui adanya perubahan orientasi kedepan bahwa "Belanja untuk mendapatan Pendapatan", (2) Pemetaan strategi peningkatan IKK pada 29 Kabupaten/Kota di provinsi papua perlu mengacu pada potensi baseline PAD dan potensi teoritis yang terkandung dalam peraturan daerah mengenai PAD.
\end{abstract}

Kata Kunci : IKK, Indeks Kemampuan Keuangan, Pendapatan Asli Daerah

\section{PENDAHULUAN}

\section{A. Latar Belakang}

Kabupaten Semangat Otonomi Daerah yang telah berlangsung saat ini, belum memberikan orientasi yang cukup besar dalam pengelolaan Keuangan Daerah pada tingkatan daerah. Semangat ini memberikan dampak terhadap adanya peran Pemerintah Dalam Pengelolaan Keuangan Daerah. Poin sentral yang perlu mendapatkan perhatian Pemerintah Daerah ialah dari segi Pendapatan Daerah. Pelaksanaan pembangunan ekonomi pra otonomi daerah dilakukan secara sentralisasi, namun berdampak pada semakin bergantungnya pemerintah daerah terhadap pusat (Mardiasmo, 2002).

Kebijakan otonomi keuangan daerah, akhirnya dilaksanakan pada 2001, yang berlandaskan pada undang-undang Nomor 25 Tahun 1999. Undang-undang ini terus diperbaharui, yang akhirnya akan membawa perubahan yang mendasar mengenai hubungan keuangan antara pusat dan daerah. Kondisi ini, didukung pula dengan isu bahwa proses bisnis dalam pengelolaan keuangan daerah terlalu panjang hal ini dapat mengindikasikan peluang penyalahgunaan keuangan daerah antara eksekutif dan legislatif (Soeharjoto, 2018). Pada Tahun 2020 saat ini dan sekaligus sebagai orientasi pada Tahun Anggaran 2021, mekanisme Pengelolaan Keuangan Daerah diperhadapkan dengan sejumlah perubahan-perubahan yang cukup mendasar pasca diterbitkannya Peraturan Pemerintah Nomor 12 Tahun 2019 Tentang Pengelolaan Keuangan Daerah, dalam kerangka implementasi ketentuan Pasal 293 dan Pasal 330 Undang-Undang Nomor 23 Tahun 2014 Tentang Pemerintahan Daerah.

Dalam konteks Perubahan Regulasi yang terjadi secara terus menerus, dikaitkan dengan tuntutan Otonomi Daerah yang mengaharapkan adanya Kinerja Keuangan Daerah dari Struktur Pendapatan Daerah. Perubahan ini diindikasikan hanya terfokus pada Struktur Belanja Daerah. Isu ini jika dikaitkan dengan isu analisis ketergantungan fiskal, terlihat pada Anggaran Pendapatan dan Belanja Daerah (APBD), untuk menutupi biaya Belanja Daerah, dibiayai dengan Pendapatan Asli Daerah (PAD), yang ditunjang dengan Subsidi dan Bantuan Pusat yang semakin membesar. Hal ini, terjadi karena pemerintah daerah kehilangan keleluasaan melakukan tindakannya (Local Discrection), terutama dalam pengambilan 
keputusan penting, yang disebabkan semakin banyaknya intervensi dari Pemerintah Pusat terhadap daerah (Kuncoro, 2004).

Sepanjang berjalananya Kebijakan Otonomi Daerah di Indonesia, berbagai isu Kemampuan Keuangan Daerah mendapatkan perhatian serius Pemerintah Pusat, karena semangat Desentralisasi Fiskal masih berjalan kaku di beberapa Provinsi di Indonesia. Hasil Riset Menunjukkan, kondisi yang diharapkan ternyata berbanding terbalik dengan kenyataan. Keadaan tersebut membuat daerah ketergantungan terhadap dana transfer dari pemerintah pusat. Menurut Menteri Keuangan (Menkeu) Sri Mulyani Indrawati, ketergantungan daerah terhadap TKDD masih sangat tinggi. Secara rata-rata nasional, ketergantungan Anggaran Pendapatan Dan Belanja Daerah (APBD) terhadap TKDD sebesar 80.10 persen. Sementara, kontribusi Pendapatan Asli Daerah (PAD) hanya sekitar 12.87 persen (Yoga, 2019). Melalui kondisi faktual ini, ditemukan suatu etos sistematis yang perlu dilakukan koordinasi antara Pemerintah Pusat dan Daerah dalam melihat secara bersama mengenai Desentralisasi Fiskal.

Gambaran nasional mengenai kondisi faktual desentralisasi fiskal, memberikan rambu-rambu bagi Daerah untuk terus mengoptimalkan keberadaan Sumber Daya Alam (SDA) dan Sumber Daya Manusia (SDM). Sepintas mengenai Kinerja Keuangan Daerah di Provinsi Papua periode tahun 2010-2017 derajat fiskal berkisar pada angka 7.61 persen, cukup riskan dimana struktur pendapatan daerah didominasi oleh TKDD dari Pemerintah Pusat, hal ini memberikan dampak pada Kemampuan membiayai belanja sendiri yang cukup kecil hanya 7.72 persen pada periode tahun 2010-2017.

Keberhasilan pembangunan dengan menggunakan sistem desentralisasi bergantung pada kesiapan daerah dalam menghimpun dana. Peningkatan pembangunan akan dapat tercapai dengan melakukan mengalokasikan dana untuk sektor riil dan tidak terjadinya asymmetric information, yang akan memberikan multiplier effect yang baik (Soeharjoto, 2018). Oleh karena itu, perlu adanya sebuah peta Kemampuan Keuangan Daerah di Provinsi Papua sebagai pijakan makro pengelolaan Sumber Daya Alam (SDA) dan Sumber Daya Manusia (SDM) dalam proses sistematis memperkaya semangat Otonomi Daerah di Provinsi Papua.

\section{B. Tujuan Penelitian}

Dengan berbagai argumentasi konseptual dan temuan empiris mengenai isu desentralisasi fiskal yang terjadi di Provinsi Papua, maka penelitian ini memiliki tujuan sebagai berikut:

1. Mengukur peranan Pendapatan Asli Daerah (PAD) terhadap Belanja Daerah dan Elastisitas Pertumbuhan Ekonomi pada 29 Kabupaten/Kota di Provinsi Papua.

2. Mengukur Indeks Komposit Kemampuan Keuangan Daerah pada 29 Kabupaten/Kota di Provinsi Papua

\section{METODE PENELITIAN}

\section{A. Lokasi Penelitian}

Penelitian ini dilaksanakan dengan Lokus pada Pemerintah Daerah 29 Kabupaten/Kota di Provinsi Papua. Sedangkan Fokus pada penelitian ini mengungkap Pendapatan Asli Daerah (PAD), Belanja Daerah, dan Pertumbuhan Ekonomi dengan rentang tahun pengamatan 5 (Lima) Tahun 2015-2019.

\section{B. Metode Analisis}

Secara garis besar penelitian ini pada prinsipnya menggunakan Pendekatan Kuantitatif dalam mengungkap berbagai kecenderungan yang terjadi pada isu penelitian dan juga proses pengukuran fokus penelitian. Kebutuhan data dalam penelitian ini yakni data sekunder yang ber-sumber dari beberapa lembaga resmi antara lain: (1) Direktorat Jenderal Perimbangan Keuangan (DJPK) RI, dan (2) Badan Pusat Statistik (BPS) Provinsi Papua. Proses Pengumpulan Data melalui mekanisme studi kepustakaan pada beberapa dokumen antara lain: (1) Target/Realisasi APBD Pokok/Perubahan se-Indonesia tahun 2015-2019, (2) Data Dalam Angka (DDA) Provinsi Papua Tahun 2015-2019, (3) Produk Domestik Regional Bruto (PDRB) Provinsi Papua Tahun 2015-2019, (4) Regulasi Keuangan Daerah dan Literatur Jurnal Penelitian yang berkaitan secara langsung terhadap isu penelitian ini. Metode analisis data yang diterapkan pada penelitian ini yaitu deskriptif kuantititaif pada indikator Peranan PAD terhadap Belanja Daerah, Pertumbuhan PAD, dan Elastisitas PAD terhadap Pertumbuhan Ekonomi. Berikut disajikan tahapan dan mekanisme analisis data penelitian ini: 


\section{Perhitungan Indeks Tunggal Dimensi XS (PAD-BD), XG (PAD), XE (PAD-PE)}

$$
\text { Indeks } X_{i . j}=\frac{X_{i, j}-\min }{\max -\min }
$$

Keterangan:

$X \quad=$ Indeks Tunggal

$i \quad=$ Dimensi XS, XG, dan XE

$j=$ Lokus Pengamatan

$\min =$ Nilai Minimum pada setiap array Data XS, XG, dan XE

$\max =$ Nilai Maksimum pada setiap array Data XS, $X G$, dan $X E$

\section{Indeks Komposit Kemampuan Keuangan Daerah (IKK)}

$$
I K K_{j}=\frac{X S_{j}+X G_{j}+X E_{j}}{3}
$$

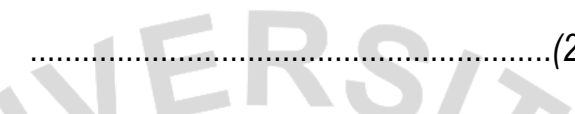

\section{Keterangan:}

IKK= Indeks Komposit

$j=$ Lokus Pengamatan

$X S=$ Dimensi Share PAD-BD

$X G=$ Dimensi Growth PAD

$\mathrm{XE}=$ Dimensi Elastisitas PAD-PE

Dalam konteks interpretasi hasil analisis data, dilakukan kategorisasi kriteria penilaian secara statistik berdasarkan perolehan nilai IKK pada masing-masing Kabupaten/Kota di Provinsi Papua. 1/3 pertama dikelompokkan dan dikategorikan sebagai Kabupaten/Kota yang mempunyai kemampuan keuangan "TINGGI". 1/3 kedua dikelompokkan dan dikatagorikan sebagai Kabupaten/Kota yang mempunyai kemampuan keuangan "SEDANG". 1/3 terakhir dikelompokkan dan dikatagorikan sebagai Kabupaten/Kota yang mempunyai kemampuan keuangan "RENDAH" (Deddyk, 2003).

\section{HASIL DAN PEMBAHASAN}

Wajah Provinsi Papua tidak terlepas dari potret 29 Kabupaten/Kota, kesatuan pandang dan keberagaman orientasi dalam memahami isu desentralisasi fiskal memberikan tantangan tersendiri dalam menyegarkan semangat otonomi daerah di Provinsi Papua. Temuan empiris mengenai peran Pendapatan Asli Daerah di Provinsi Papua dan Kabupaten/Kota masih relatif rendah walaupun jumlahnya terus meningkat. Minimnya sumber pajak serta kurangnya peratuan daerah terkait perpajakan menyebabkan rasio pajak terhadap PDRB di banyak Kabupaten/Kota masih dibawah 1 Persen (Bank Dunia, 2014).

Kinerja masa lampau yang terjadi pada tahun 2014, tetap tumbuh subur hingga pada periode tahun 2015-2019, dimana peranan PAD terhadap BD pada 29 Kabupaten/Kota hanya mampu berkisar pada angka 3.28 persen artinya sebanyak 96.72 persen BD sangat tergantung pada pemerintah pusat. Karakteristik Postur APBD di Kabupaten/Kota memiliki Pola Instruktif, hal ini sangat berdampak buruk pada proses pembangunan sosial dan ekonomi pada masingmasing Kabupaten/Kota, dimana jika terjadi ketidakpastian proses transfer pemerintah pusat, maka secara otomatis mempengaruhi kuantitas dan kualitas dari proses pelaksanaan APBD di Kabupaten/Kota di Provinsi Papua. Jika situasi ini dikaitkan dengan konsep teoritis bahwa "APBD merupakan instrumen kebijakan utama bagi pemerintah daerah, menduduki porsi sentral dalam upaya pengembangan kapabilitas dan efektivitas pemerintah daerah" (Mardiasmo, 2002). Maka dapat 
diindikasikan secara hirarkis ketergantungan keuangan ini mampu memberikan dampak negatif terhadap efektifitas pelayanan publik pada masyarakat. Namun sejauh ini, pada peridoe tahun 2015-2019 terdapat beberapa Kabupaten/Kota yang memiliki peranan PAD terhadap BD cukup besar dibandingkan Kabupaten/Kota lainnya antara lain: Mimika, Kota Jayapura, Biak Numfor, Kepulauan Yapen, Jayapura, Merauke, Jayawijaya, Nabire, Asmat, dan Supiori.

\section{Gambar 1. Rerata Peranan PAD Terhadap BD 29 Kubupaten/Kota di Provinsi Papua Tahun 2015-2019}

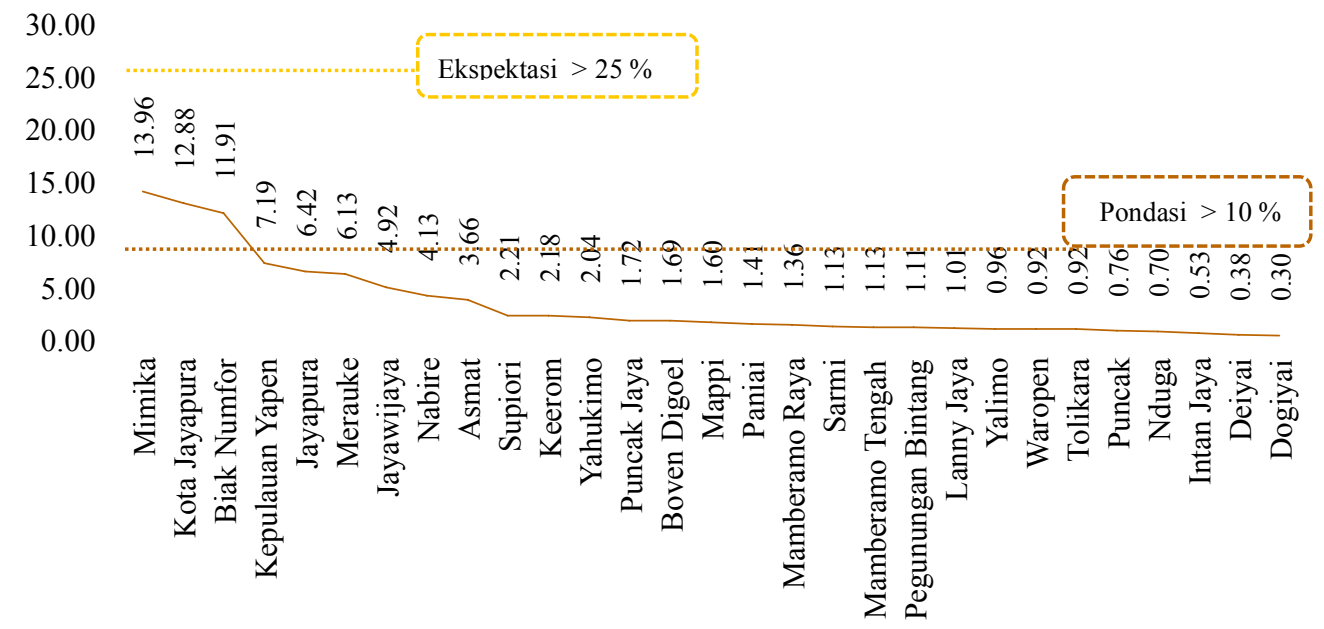

Sumber: Data diolah, (2020)

Dalam konteks peranan PAD terhadap BD pada 29 Kabupaten/Kota di Provinsi Papua, melalui perkembangan informasi pada gambar 1 , menunjukan adanya ketidakseimbangan pendapatan asli daerah dengan tuntutan belanja daerah yang disajikan dalam struktur belanja daerah. Kecenderungan peningkatan belanja daerah, rerata realisasi BD 29 Kabupaten/Kota secara agregat mencapai Rp.1,336,443,232,958,- sedangkan rerata realisasi PAD hanya berkisar Rp.51,975,949,322,-. Tentunya dengan kondisi ini, membuat adanya dilema pada pemerintah daerah Kabupaten/Kota dimana tuntutan aspirasi masyarakat yang dicerminkan melalui BD tidak sejalan dengan kemampuan rill keuangan daerah yang dimiliki pemerintah daerah. Dengan fenomena ini, perlu adanya harmonisasi secara menyeluruh yang perlu diakomodir oleh pemerintah daerah Provinsi Papua dalam membangun sudut pandang bersama untuk mampu membangun pondasi kapasitas fiskal paada posisi 10 persen. Titik ini merupakan strategi kebijakan yang memfokuskan pada orientasi kebangkitan desentralisasi fiskal di Provinsi Papua. Dalam konsep teoritis kebijakan publik menyatakan bahwa kebijakan publik adalah pemanfaatan yang strategis terhadap sumberdaya-sumberdaya yang ada untuk memecahkan masalahmasalah publik atau pemerintah (Chandler dkk, 1988). Tentunya isu strategis desentralisasi fiskal yang terjadi pada Kabupaten/Kota di Provinsi Papua, perlu diangkat dan dikemas sebagai isu yang bersifat "urgent", salah satu pengambilan kebijakan publik yang penting dan urgent ialah memiliki nilai alasan ilmiah (Wahab dalam Salam, 2016).

Pengambilan kebijakan publik dalam kerangka mengungkit PAD pada 26 Kabupaten di Provinsi Papua, yang memiliki kecenderungan PAD terhadap BD masih dibawah 10 persen tentunya perlu skenario dalam jangka panjang. Menciptakan daya ungkit ini tentunya berdampak pada eksploitasi keradaan sumber daya pada 26 Kabupaten tersebut. Salah satu faktor yang dapat mendorong semakin tingginya kemampuan keuangan daerah adalah pertumbuhan ekonomi, kenaikan PAD merupakan ekses dari pertumbuhan ekonomi (Saragih, 2003) selain itu pendapat lain bahwa pertumbuhan PAD seharusnya sensitif terhadap pertumbuhan ekonomi (Deddyk, 2003). 


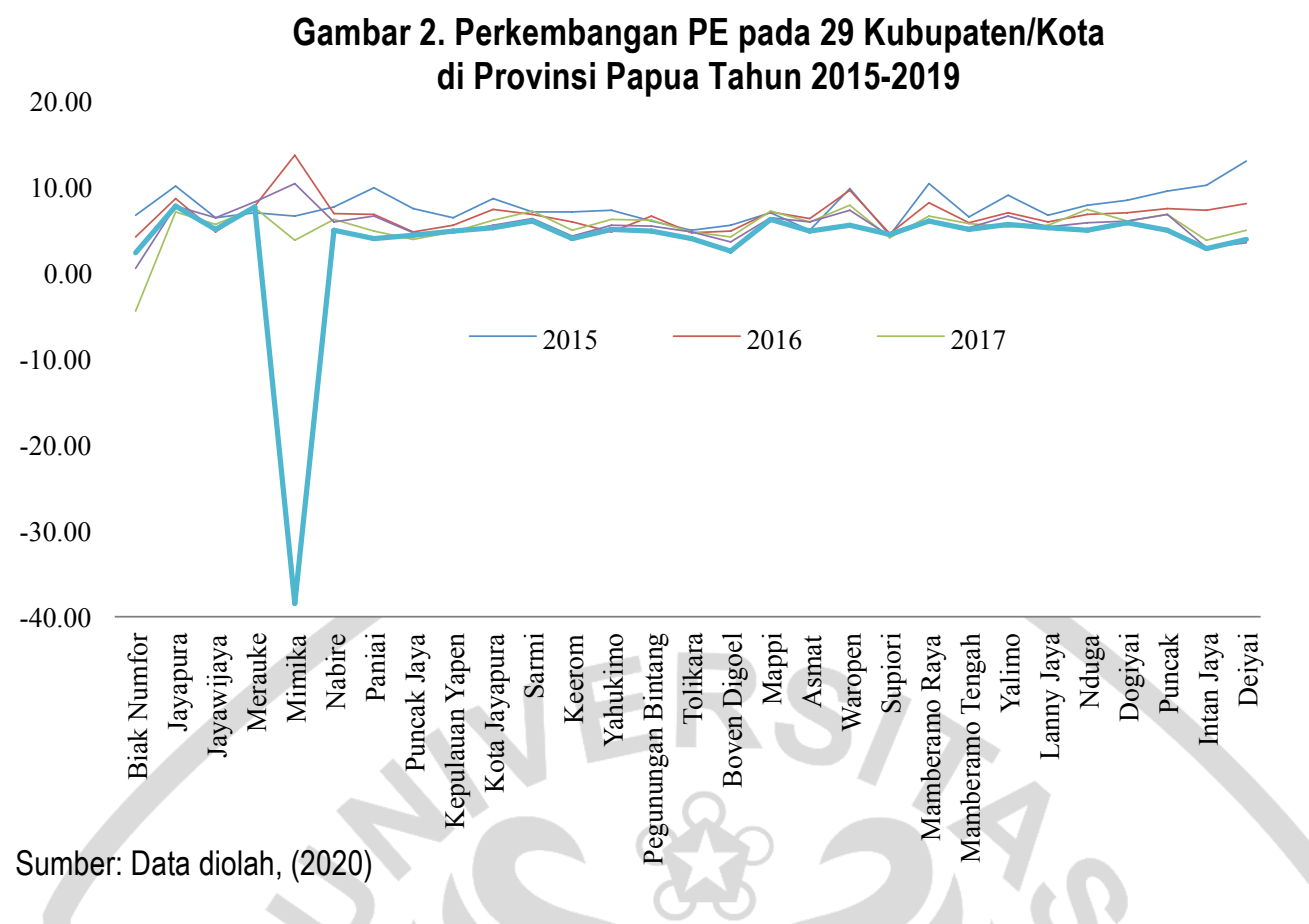

Bertolak dari kerangka teoritis pada pembahasan sebelumnya, bahwa terdapat peranan ekonomi daerah melalui indikator makro PE di 29 Kabupaten/Kota. Periode tahun 2015-2019 perlu dijadikan momentum reformulasi kebijakan ekonomi pada masing-masing daerah. Pada gambar 2, diatas, menunjukkan kinerja pelaksanan pembangunan sepanjang 5 tahun terakhir dimana secara rata-rata pertumbuhan ekonomi Kabupaten/Kota di Provinsi Papua berkisar pada angka 5.65 persen. Terdapat 2 Kabupaten yang memiliki pertumbuhan negatif yakni Biak Numfor pada tahun 2017 mencapai -4.57 persen dan Kabupaten Mimika pada tahun 2019 mencapai -38.52 persen, kondisi ini dapat dikatakan terjadinya kontraksi ekonomi pada kabupaten Mimika. Kontraksi ekonomi yang terjadi di Mimika membawa dampak besar terhadap pertumbuhan ekonomi tahun 2019 di Provinsi Papua. Secara keseluruhan kinerja PE 29 Kabupaten/Kota di Provinsi Papua terlihat cukup baik dengan pola karakteristik yang berbeda-beda terdapat beberapa Kabupaten yang memiliki kecenderungan stagnan. Dengan berbagai isu yang dapat dikemukan pada gambar 2 diatas, maka dapat diindikasikan adanya hubungan yang cukup kuat antara pergerakan pertumbuhan realisasi PAD, isu mengenai peranan PAD terhadap BD dengan pergerakan ekonomi daerah. Hal ini dibuktikan dengan kondisi historis kinerja pertumbuhan PAD, relatif belum mampu menguasai stuktur APBD Kabupaten/Kota di provinsi papua sepanjang periode tahun 2015-2019. Selain itu juga, pergerakan PE antar Kabupaten/Kota yang memiliki karakteristik yang berbeda.

Melalui harapan teoritis kebijakan Otonomi Daerah yang mana selanjutnya dilegalkan melalui beberapa produk hukum, dalam kerangka legitimasi pelaksanaan kewenangan pada masing-masing daerah. Dimana dalam proses pelaksanaan kebijakan tersebut terdapat hambatan yang substansi, dimana salah satu semangat otonomi daerah itu melalui kinerja kemandirian keuangan daerah belum mampu direalisasikan oleh pemerintah daerah. Fenomena yang sama disumbangkan dari 29 Kabupaten/Kota di provinsi papua, dengan berbagai temuan empiris dan juga fenomena yang tergambarkan melalui informasi data dan informasi di Provinsi Papua. Maka perlu adanya kebijakan terobosan yang inovatif yang sepatutnya disikapi oleh masing-masing pemerintah daerah 29 Kabupaten/Kota di Provinsi Papua. Dalam menunjang proses tersebut diperlukan peta kemampuan keuangan daerah yang mengungkap secara komprehensif mengenai hubungan deksriptif sebab akibat yang terjadi selama ini mengenai fenomena PAD di Provinsi Papua. 
Tabel 1. Rerata Nilai Indeks Kemampuan Keuangan Daerah (IKK) di Provinsi Papua Tahun 2015-2019

\begin{tabular}{|l|l|l|l|l|l|l|l|l|}
\hline \multirow{2}{*}{ No } & \multirow{2}{*}{ Kabupaten/Kota } & \multicolumn{3}{l|}{ Rerata Historis } & \multicolumn{2}{l|}{ Dimensi } \\
\cline { 2 - 8 } & & Pad-Bd & Pad & Pe & Xs & Xg & Xe & \\
\hline 1 & Biak Numfor & 13.96 & 21.28 & 1.74 & 50.19 & 2.10 & 44.07 & 37.61 \\
\hline 2 & Jayapura & 12.88 & 4.76 & 8.17 & 78.76 & 5.69 & 7.83 & 87.06 \\
\hline 3 & Jayawijaya & 11.91 & 0.85 & 5.55 & 72.28 & 70.28 & 89.18 & 73.72 \\
\hline 4 & Merauke & 7.19 & 1.95 & 7.54 & 68.22 & 56.49 & 44.82 & 3.22 \\
\hline 5 & Mimika & 6.42 & 1.96 & -0.91 & 72.90 & 29.83 & 55.00 & 24.74 \\
\hline 6 & Nabire & 6.13 & 18.93 & 6.21 & 52.00 & 15.42 & 28.47 & 76.91 \\
\hline 7 & Paniai & 4.92 & -1.10 & 6.33 & 62.11 & 95.08 & 66.33 & 55.08 \\
\hline 8 & Puncak Jaya & 4.13 & 17.27 & 4.91 & 47.92 & 14.51 & 0.34 & 33.29 \\
\hline 9 & Kepulauan Yapen & 3.66 & 25.09 & 5.12 & 42.99 & 11.88 & 3.49 & 32.28 \\
\hline 10 & Kota Jayapura & 2.21 & 13.18 & 6.46 & 65.07 & 17.87 & 4.47 & 45.71 \\
\hline 11 & Sarmi & 2.18 & 20.34 & 6.59 & 31.89 & 22.42 & 4.07 & 8.11 \\
\hline 12 & Keerom & 2.04 & 19.10 & 5.15 & 49.15 & 6.82 & 4.60 & 43.86 \\
\hline 13 & Yahukimo & 1.72 & 14.17 & 5.65 & 66.06 & 7.87 & 1.94 & 58.84 \\
\hline 14 & Pegunungan Bintang & 1.69 & 3.17 & 5.70 & 89.68 & 45.87 & 54.40 & 25.68 \\
\hline 15 & Tolikara & 1.60 & 1.47 & 4.52 & 58.34 & 62.38 & 61.95 & 24.69 \\
\hline 16 & Boven Digoel & 1.41 & -1.72 & 4.01 & 65.09 & 97.98 & 71.11 & 56.60 \\
\hline 17 & Mappi & 1.36 & 6.78 & 6.65 & 80.85 & 74.88 & 52.30 & 11.46 \\
\hline 18 & Asmat & 1.13 & 3.10 & 5.46 & 78.56 & 24.61 & 26.16 & 45.23 \\
\hline 19 & Waropen & 1.13 & 19.87 & 7.89 & 66.43 & 12.08 & 18.72 & 84.75 \\
\hline 20 & Supiori & 1.11 & 27.12 & 4.24 & 39.44 & 53.99 & 23.67 & 22.45 \\
\hline 21 & Mamberamo Raya & 1.01 & 7.65 & 7.32 & 70.91 & 70.63 & 40.05 & 13.07 \\
\hline 22 & Mamberamo Tengah & 0.96 & 1.09 & 5.56 & 52.60 & 14.40 & 14.77 & 33.28 \\
\hline 23 & Yalimo & 0.92 & 1.03 & 6.58 & 81.61 & 53.78 & 29.07 & 18.14 \\
\hline 24 & Lanny Jaya & 0.92 & 4.67 & 5.64 & 67.35 & 14.72 & 7.63 & 50.08 \\
\hline 25 & Nduga & 0.76 & 7.61 & 6.45 & 74.81 & 40.47 & 25.66 & 25.78 \\
\hline 26 & Dogiyai & 0.70 & 2.83 & 6.54 & 55.98 & 91.48 & 50.08 & 52.20 \\
\hline 27 & Puncak & 0.53 & 1.30 & 6.99 & 55.45 & 42.29 & 36.36 & 1.05 \\
\hline 28 & Intan Jaya & 0.38 & 4.69 & 5.29 & 75.54 & 66.36 & 45.64 & 6.03 \\
\hline 29 & Deiyai & 0.30 & 11.25 & 6.55 & 63.13 & 11.25 & 2.11 & 51.18 \\
\hline
\end{tabular}

Sumber: Data diolah, (2020)

Berlandaskan pada hasil analisis data kemampuan keuangan daerah yang termuat pada tabel 1 diatas ini, secara deskriptif perolehan nilai minimum pada pada masing-masing dimensi antara lain, dimensi XS (31.89 persen), dimensi XG (2.10 persen), dan dimensi XE (0.34 persen) sedangkan untuk nilai perolehan indeks komposit IKK (1.05 persen). Sedangkan untuk perolehan nilai maksimum pada dimensi XS (89.68 persen), dimensi XG (97.98 persen), dan dimensi XE (31.53 persen) sedangkan untuk nilai perolehan untuk indeks komposit IKK (38.00 persen). Melalui gambaran ini, secara komparasi antar Kabupaten/Kota di Provinsi Papua dapat terpetakan dengan jelas kedudukan probelamatika kemampuan keuangan daerah selama ini. Salah satu kasus berdasarkan perolehan hasil informasi ilmiah pada tabel 1 diatas, Kabupaten Biak Numfor memiliki kecenderungan historis dimensi PAD, BD, dan PE yang cukup baik dibandingkan dengan Jayawijaya, namun perolehan hasil IKK menunjukkan IKK Kabupaten Jayawijaya 73.72 persen sedangkan Kabupaten Biak Numfor hanya berkisar 37.61 persen, permasalahan kinerja yang terjadi pada Kabupaten Biak Numfor terletak pada dimensi Xg dimana nilai Xg Kabupaten Jayawijaya diatas nilai minimum. Melalui peta kemampuan ini diperoleh berbagai rumusan indikasi starting point dalam mencipatakan sudut pandang bersama untuk mampu membangun pondasi kapasitas fiskal.

Dalam proses interpretasi ilmiah, diperlukan penilaian IKK pada setiap tahun pengamatan, hal ini sebagai informasi pendukung dalam melihat perkembangan nilai perolehan IKK pada Kabupaten/Kota di Provinsi Papua sepanjang tahun 2015-2019. Melalui tampilan informasi pengolahan data pada tabel 2 dibawah ini rerata nilai IKK mengalami perkembangan yang cukup kurang stabil dimana pada tahun 2015 nilai rerata IKK sebesar 39.94 persen pada tahun 2015 mengalami 
kenaiakan sebesar 2.26 poin menjadi 42.20 persen. Namun kondisi capaian ini tidak semulus pada tahun 2017 dimana terjadi penurunan nilai IKK sebesar -2.81 poin menjadikan nilai IKK tahunan hanya 39.39 persen, keparahan ini berlangsung hingga pada tahun 2018 dengan penurunan poin sangat tajam sebesar -3.62. Pada tahun 2019 memberikan pertanda baik dengan kenaikan perolehan nilai IKK menjadi 38.91 persen, walaupun posisi ini tidak sebanding dengan kinerja historis pada IKK tahun 2016.

Tabel 2. Penilaian Berdasarkan Kategori Nilai Indeks Kemampuan Keuangan Daerah (IKK) di Provinsi Papua Tahun 2015-2019

\begin{tabular}{|c|c|c|c|c|c|c|}
\hline \multirow{2}{*}{ No } & \multirow{2}{*}{ Kabupaten/Kota } & \multicolumn{5}{|c|}{ Penilaian Kategori IKK } \\
\hline & & 2015 & 2016 & 2017 & 2018 & 2019 \\
\hline 1 & Biak Numfor & Sedang & Tinggi & Tingqi & Sedang & Sedang \\
\hline 2 & Jayapura & Tinggi & Tinggi & Rendah & Sedang & Tinggi \\
\hline 3 & Jayawijaya & Tinggi & Tinggi & Tinggi & Tinggi & Tinggi \\
\hline 4 & Merauke & Rendah & Sedang & Sedang & Tinggi & Sedang \\
\hline 5 & Mimika & Sedang & Sedang & Rendah & Rendah & Tinggi \\
\hline 6 & Nabire & Tinggi & Rendah & Rendah & Sedang & Tinggi \\
\hline 7 & Paniai & Tinggi & Tinggi & Tinggi & Tinggi & Sedang \\
\hline 8 & Puncak Jaya & Sedang & Sedang & Sedang & Tinggi & Tinggi \\
\hline 9 & Kepulauan Yapen & Tinggi & Rendah & Tinggi & Rendah & Rendah \\
\hline 10 & Kota Jayapura & Sedang & Rendah & Sedang & Tinggi & Rendah \\
\hline 11 & Sarmi & Rendah & Sedang & Sedang & Rendah & Tinggi \\
\hline 12 & Keerom & Tinggi & Tinggi & Sedang & Rendah & Sedang \\
\hline 13 & Yahukimo & Tinggi & Tinggi & Rendah & Rendah & Rendah \\
\hline 14 & Pegunungan Bintang & Sedang & Tinggi & Tinggi & Sedang & Rendah \\
\hline 15 & Tolikara & Rendah & Rendah & Sedang & Tinggi & Sedang \\
\hline 16 & Boven Digoel & Tinggi & Sedang & Sedang & Sedang & Tinggi \\
\hline 17 & Mappi & Rendah & Tinggi & Tinggi & Rendah & Sedang \\
\hline 18 & Asmat & Sedang & Rendah & Rendah & Rendah & Tinggi \\
\hline 19 & Waropen & Tinggi & Rendah & Sedang & Tinggi & Sedang \\
\hline 20 & Supiori & Rendah & Sedang & Sedang & Sedang & Sedang \\
\hline 21 & Mamberamo Raya & Rendah & Rendah & Tinggi & Sedang & Rendah \\
\hline 22 & Mamberamo Tengah & Sedang & Sedang & Sedang & Rendah & Rendah \\
\hline 23 & Yalimo & Rendah & Sedang & Rendah & Sedang & Rendah \\
\hline 24 & Lanny Jaya & Tinggi & Sedang & Tinggi & Tinggi & Tinggi \\
\hline 25 & Nduga & Sedang & Sedang & Tinggi & Tinggi & Tinggi \\
\hline 26 & Dogiyai & Sedang & Tinggi & Rendah & Tinggi & Sedang \\
\hline 27 & Puncak & Rendah & Rendah & Rendah & Sedang & Sedang \\
\hline 28 & Intan Jaya & Rendah & Tinggi & Tinggi & Rendah & Rendah \\
\hline 29 & Deiyai & Sedang & Rendah & Rendah & Sedang & Rendah \\
\hline
\end{tabular}

Sumber: Data diolah, (2020)

Mengacu pada perolehan informasi pada tabel 2 diatas ini, batasan minimal penilaian kategori "Tinggi" dengan nilai 50.91 persen, sedangkan untuk kategori IKK "Sedang" dengan nilai minimal 19.95 persen, dan untuk kategori "Rendah" memiliki nilai minimal 0.95 persen. Berdasarkan batasan minimal tersebut, dapat dipetakan Kabupaten/Kota yang secara konsisten memiliki kriteria "Tinggi" hanya pada Kabupaten Jayawijaya. Sedangkan untuk Kabupaten Paniai, perolehan konsistensi penilaian "Tinggi" pada tahun 2015-2018 sedangkan pada tahun 2019 mendapatkan penilaian "Sedang". Sedangkan untuk beberapa Kabupaten/Kota yang dapat diasumsikan sebagai barometer pembangunan, seperti Kota Jayapura dan merauke hanya mampu mendapatkan perolehan penilaian kategori IKK "Tinggi" pada tahun 2018. Selain itu, Kabupaten Mimika dengan keberadaan peranan sektor pertambangan belum mampu menunjang capaian kinerja IKK sepanjang tahun 2017-2018 yang secara berturut-turut menghasilkan penilaian "Rendah". Hal ini tentunya tak sebanding 
dengan capaian yang dihasilkan oleh Kabupaten yang memiliki akses relatif sulit seperti Kabupaten Lanny Jaya, dan Nduga dimana mendapatkan penilaian kinerja IKK "Tinggi" pada tahun 2017-2019. Hal ini disebabkan adanya perolehan kinerja pada setiap dimensi pada tabel 1, dimana perolehan nilai indeks perananan PAD terhadap Belanja Daerah relatif lebih besar dibandingkan Kota Jayapura, dimana untuk kabupaten Lanny Jaya sebesar 67.35 persen dan Kabupaten Nduga mendapatkan nilai indkes 74.81 persen, sedangkan Kota Jayapura hanya memperoleh nilai indeks 65.07 persen. Kondisi serupa terjadi pada dimensi Elastisitas PAD yang mana Kota Jayapura hanya sebesar 4.47 persen. Dengan berbagai fakta ilmiah yang dijumpai dalam penelitian ini, pemerintah Provinsi Papua dan 29 Kabupaten/Kota perlu meletakkan pondasi masa depan dengan langkah "REFORMULASI ORIENTASI KONSEP PRAKTISI MENGENAI PENDAPATAN ASLI DAERAH (PAD)".

\section{PENUTUP}

Mengacu pada hasil temuan empiris dan didukung dengan temuan fakta ilmiah kinerja historis, serta mempertimbangkan kerangka konseptual. Maka dapat ditarik kesimpulan umum hasil penelitian ini bahwa: (1) Kinerja kuantitas PAD 29 Kabupaten/Kota di Provinsi Papua yang sebatas terukur dari nilai dekriptif kontribusi dan pertumbuhan tidak dapat dijadikan satu-satunya tolak ukur dalam memandang kinerja realisasi PAD di Provinsi Papua, (2) Pergerakan percepatan pertumbuhan ekonomi yang cenderung lambat selama ini, belum mampu mengungkit penerimaan PAD pada 29 Kabupaten/Kota di Provinsi Papua, (3) Kabupaten/Kota yang notabene menjadi barometer, belum sanggup menunjukkan kinerja secara konsisten dalam penilaian Indeks Kemampuan Keuangan Daerah di Provinsi Papua. Dengan ini, rekomendasi aplikatif yang hendak disikapi oleh pemerintah daerah baik Provinsi Papua dan pemerintah Kabupaten/Kota ialah: (1) penyamaan persepsi berbasiskan pada fakta ilmiah dan konseptual mengenai kedudukan dari PAD itu sendiri, perlu adanya perubahan orientasi kedepan bahwa "Belanja untuk mendapatan Pendapatan", (2) Pemetaan strategi peningkatan IKK pada 29 Kabupaten/Kota di Provinsi Papua perlu mengacu pada potensi baseline PAD dan potensi teoritis yang terkandung dalam peraturan daerah mengenai PAD.

\section{DAFTAR PUSTAKA}

[1]. Bank Dunia. 2014. Laporan Analisis Keuangan Publik Papua. Jakarta

[2]. Chandler, Ralph C dkk. 1988. The Public Administration Dictionary. John Wiley \& Sons

[3]. Deddyk, "Peta Kemampuan Keuangan Provinsi Dalam Era Otonomi Daerah", 2003, <https://www.bappenas.go.id/files/4613/5230/1470/15peta-kemampuankeuangan-provinsi-dalam-era-otonomi-daerah-tinjauan-atas-kinerja-pad-dan-upaya-yang-dilakukan-daerah_20081123002641_14.pdf > [diakses pada 13 April 2020

[4]. Kuncoro, Mudrajad. 2004. Otonomi dan Pembangunan Daerah: Reformasi, Perencanaan, Strategi, dan Peluang. Jakarta: Erlangga.

[5]. Mardiasmo, "Otonomi Daerah Sebagai Upaya Memperkokoh Basis Perekonomian Daerah", 2002, <http://www.ekonomirakyat.org/edisi_4/artikel_3.htm> [diakses pada 13 April 2020]

[6]. Mardiasmo. 2002. Otonomi dan Manajemen Keuangan Daerah. Yogyakarta: ANDI.

[7]. Peraturan Pemerintah Republik Indonesia Nomor 12 Tahun 2019. Tentang Pengelolaan Keuangan Daerah

[8]. Salam, Asbudi. 2016. Implementasi Kebijakan Peraturan Bupati Nunukan No 40 Tahun 2013 Tentang Percepatan Penganekaragaman Konsumsi Pangan Berbasisi Sumber Daya Lokal Di Kabupaten Nunukan. Tesis. Univ. Terbuka Jakarta

[9]. Saragih, Juli Panglima. 2003. Desentralisasi Fiskal dan Keuangan Daerah dalam Otonomi. Penerbit: Ghalia Indonesia.

[10]. Soeharjoto, 2018. Kemampuan dan Kinerja Keuangan Provinsi Kalimantan. e-Journal Akuntabel. Fakultas Ekonomi dan Bisnis Universitas Mulawarman (JEBM). Volume 2 Tahun 2018

[11]. Undang-Undang Republik Indonesia Nomor 25 Tahun 1999. Tentang Perimbangan Keuangan Antara Pemerintah Pusat Dan Daerah

[12]. Undang-Undang Republik Indonesia Nomor 23 Tahun 2014, Tentang Pemerintah Daerah

[13]. Yoga, 2019. Ketergantungan Fiskal Daerah Dalam Pelaksanaan Desentralisasi Fiskal di Indonesia, 2019, <https://www.kemenkeu.go.id/publikasi/artikel-danopini/ketergantungan-fiskal-daerah-dalam-pelaksanaan-desentralisasi-fiskal-di-indonesia/ > [diakses pada 13 April 2020] 